\title{
The structure of niobium and tantalum oxides processed by con- centrated light flux *
}

\author{
${ }^{1}$ Palatnikov M., ${ }^{1}$ Shcherbina O., ${ }^{1}$ Sidorov N. and ${ }^{2}$ Bormanis K. \\ ${ }^{1}$ Institute of Chemistry and Technology of Rare Elements and Mineral Raw Materi- \\ als, Apatity, Murmansk Region, Russia, e-mail: palat_mn@chemy.kolasc.net.ru \\ ${ }^{2}$ Institute of Solid State Physics, University of Latvia, Riga, Latvia, \\ e-mail: bormanis@cfi.lu.lv
}

Received: 09.09 .2012

\begin{abstract}
The article reports on significant changes occurring in the structure under treatment of $\mathrm{Nb}_{2} \mathrm{O}_{5}$ and $\mathrm{Ta}_{2} \mathrm{O}_{5}$ ceramics by a concentrated light flux (CLF). The changes comprise, in particular, appearance of micro- and nanostructures, as well as changing type of chemical bonding and coordination number of polyhedrons. These structural changes manifest themselves in the corresponding changes in the physical properties. The influences of the CLF on the $\mathrm{Nb}_{2} \mathrm{O}_{5}$ and $\mathrm{Ta}_{2} \mathrm{O}_{5}$ ceramics turn out to be different. The number of nanosize structures appearing in the $\mathrm{Ta}_{2} \mathrm{O}_{5}$ ceramics is higher, while the changes in the chemical bonding and the coordination of polyhedrons are different. The differences observed by us are explained by differing melting temperatures of $\mathrm{Nb}_{2} \mathrm{O}_{5}$ and $\mathrm{Ta}_{2} \mathrm{O}_{5}$ and degree of covalence of the chemical bonds $\mathrm{Nb}-\mathrm{O}$ and $\mathrm{Ta}-\mathrm{O}$.
\end{abstract}

Keywords: niobium and tantalum oxides, structure, concentrated light flux, Raman scattering

PACS: $78.30 . \mathrm{Ly}, 81.05 . \mathrm{Je}$

UDC: $535.4,538.9$

\section{Introduction}

Applications of $\mathrm{Nb}_{2} \mathrm{O}_{5}$ and $\mathrm{Ta}_{2} \mathrm{O}_{5}$ oxides obtained using conventional ceramic technologies are limited because of a brittle and fragile macro-crystalline structure of these materials. Therefore one can expect that finer micro- and nanoscale structures could improve mechanical properties of the ceramics. In this respect, investigations of the micro- and nanostructures and searching for new methods of materials treatment seem to be urgent [1]. An atomic force microscopy and Raman scattering studies of the influence of concentrated light flux (CFL) on the structure of niobium and tantalum oxide ceramics have been reported earlier. In particular, the Raman spectra have been revealed to be sensitive to interactions of structural units and disordering, thus revealing fine details of irradiation-imposed structural changes, which could not be detected with a common X-ray diffraction analysis [2]. The present study is devoted to further investigations of the effect of CFL on the structure and physical properties of the above ceramics.

\section{Experimental methods}

Ceramic samples prepared from $\mathrm{Nb}_{2} \mathrm{O}_{5}$ and $\mathrm{Ta}_{2} \mathrm{O}_{5}$ that contained admixtures with the concentrations less than $5 \times 10^{-4}$ mass per cent were processed using a photo-thermal treatment in the focal

\footnotetext{
* The materials of this work have been reported at the $2^{\text {nd }}$ Ukrainian-Polish-Lithuanian Meeting on Ferroelectrics Physics (9-13 September 2012, Lviv, Ukraine).
} 
zone of an optical furnace [3]. A high-performance image analyser Thixomet ${ }^{\circledR}$ and an atomicforce microscope Nano- $\mathrm{R}^{2}$ were used to explore the micro- and macro-structures of the ceramics.

The Raman spectra of the ceramic niobium and tantalum oxides were studied in so-called 'reflection' geometry. They were excited using radiation of a MML-100M Y:Al laser (the light wavelength being $\lambda_{0}=530.5 \mathrm{~nm}$ ) and a Spectra Physics laser (the light wavelength $514.5 \mathrm{~nm}$ and the power $P=800 \mathrm{~mW}$ ). The spectra were recorded at the room temperature with a modified DFS-24 spectrometer. The parameters of the Raman bands such as the frequency, the intensity and the bandwidth, were retrieved employing a BOMEM GRAMS program.

\section{Results and discussion}

Processing of the samples by the CLF yields in the conditions, which are far from thermodynamic equilibrium ones. It is performed under fast heating and high thermal gradient in the surface layer (up to hundreds of degrees per millimetre), with the gradients in the layers located deeper in the bulk being two to five times smaller. As a consequence, all of our results should be analysed with considering a possible self-organisation under dissipation of a strong energy flux in the system under examination. A number of new stable and fractal structures considered as attractors could appear. Under the action of energy flux, the structure tends to one of the attractors, its shape and type depending on the fluctuations of different parameters, which are hardly predictable.
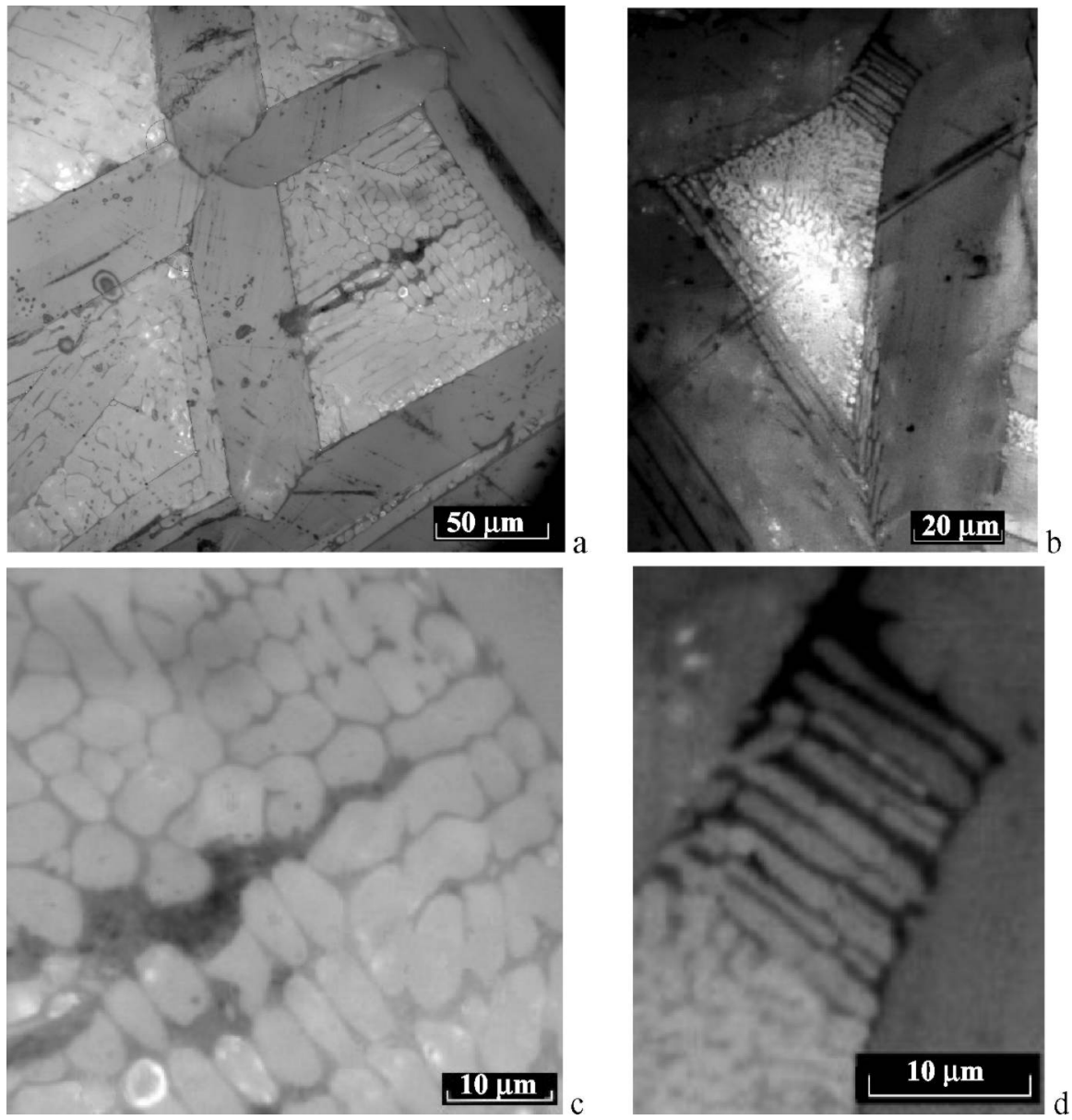

Fig. 1. Micrometer-scale fractal structures appearing in the ceramic $\mathrm{Ta}_{2} \mathrm{O}_{5}$. Picture plane is parallel to the CLF direction. The pictures are obtained with the Tixomet $^{R}$ image analysis system. 
The ceramic niobium and tantalum oxides subjected to the CLF treatment contain complex one- or two-dimensional multi-layers that are shaped as $30 \mathrm{~nm}$-thick fibres and $0.5 \mu \mathrm{m}$-thick plates and have the linear dimensions about $50 \mu \mathrm{m}$. The real structures of several ordering levels observed by us are obviously of a fractal type (see Fig. 1). At the first stage of the process, a competition takes place between the growth centres on the surface and those in the bulk of the material. The structures exhibiting fractal properties are hierarchic and similar at different scales. In other words, if there is no reference scale in the further pictures showing the structures, then it is impossible to distinguish the exact scale.

The nanosize fractal structures of the $\mathrm{Ta}_{2} \mathrm{O}_{5}$ ceramics processed by the CLF are shown in Fig. 2 and the size distributions typical for these structures are depicted in Fig. 3. The fractal nanosize structures and the corresponding size distributions for the $\mathrm{Nb}_{2} \mathrm{O}_{5}$ ceramics obtained after the CLF treatment are given by Fig. 4 and Fig. 5, respectively.

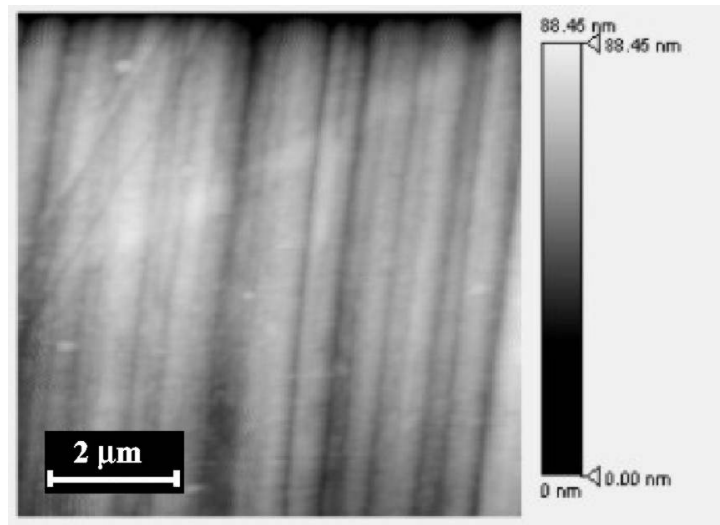

Fig. 2. Nano- $\mathrm{R}^{2}$ image of structure of the $\mathrm{Ta}_{2} \mathrm{O}_{5}$ ceramics processed by the CLF.

The CLF-processed $\mathrm{Ta}_{2} \mathrm{O}_{5}$ ceramics has a wider range of nanosize structures, when compared with the $\mathrm{Nb}_{2} \mathrm{O}_{5}$ ceramics (cf. Fig. 3 and Fig. 5). The type and the dimensions of the structure have a strong effect on the physical characteristics of the ceramic oxides of niobium and tantalum. Hence, the CLF-treated oxides reveal the micro- and nanostructures ('micro-cracks' and 'nanocracks'), which are known to suppress the effect of thermal expansion [3, 4]. Both the niobium and tantalum oxides have the phases of variable compositions $[5,6,7]$. The structures characterised by different $\mathrm{Nb}(\mathrm{Ta}) / \mathrm{O}$ ratios and thermal histories may belong to modifications of different symmetry space groups.
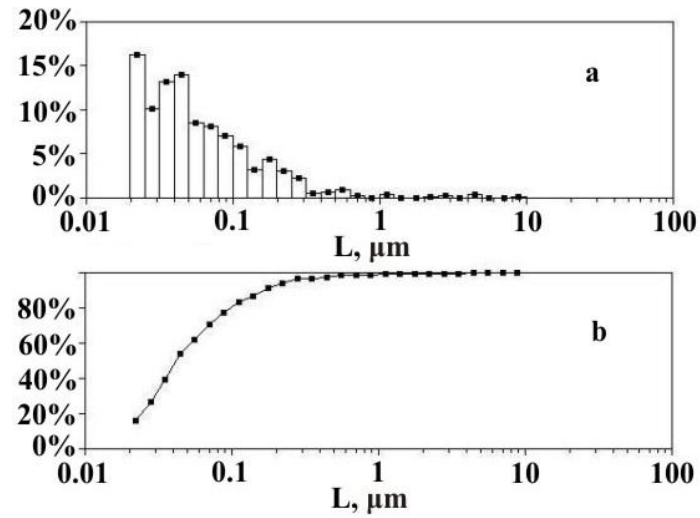

Fig. 3. Differential (a) and integral (b) size distributions for the $\mathrm{Ta}_{2} \mathrm{O}_{5}$ ceramic structures shown in Fig. 2.

At least ten stable or unstable crystalline modifications of $\mathrm{Nb}_{2} \mathrm{O}_{5}$ have been described till now (see $[5,6,8,9])$. The most abundant among them are two low-temperature modifications (an orthorhombic $(\gamma)$ and a hexagonal ( $\beta$ ) ones) and a monoclinic high-temperature $\alpha$-modification, the 
melting temperature of which is about $1500^{\circ} \mathrm{C}$. The crystallographic parameters of the three modifications are presented in Table 1.

Table 1. Crystallographic parameters of the most abundant modifications of $\mathrm{Nb}_{2} \mathrm{O}_{5}[5,6,10,11]$.

\begin{tabular}{|c|c|c|c|c|c|c|}
\hline \multirow{2}{*}{ Modification } & \multirow{2}{*}{ System } & \multicolumn{5}{|c|}{ Lattice parameters, $\AA$} \\
\cline { 3 - 7 } & & $a$ & $b$ & $c$ & $c / a$ & $\beta$ \\
\hline$\alpha-\mathrm{Nb}_{2} \mathrm{O}_{5}$ & Monoclinic & 2.134 & 3.816 & 1.947 & 0.91 & 119.694 \\
\hline$\delta-\mathrm{Nb}_{2} \mathrm{O}_{5}$ & Hexagonal & 3.61 & - & 3.925 & 1.09 & - \\
\hline$\gamma-\mathrm{Nb}_{2} \mathrm{O}_{5}$ & Rhombic & 6.19 & 3.625 & 3.94 & 0.63 & - \\
\hline
\end{tabular}

Table 2. Crystallographic parameters of the most abundant modifications of $\mathrm{Ta}_{2} \mathrm{O}_{5}[5,6,12-14]$.

\begin{tabular}{|c|c|c|c|c|c|}
\hline \multirow{2}{*}{ Modification } & \multirow{2}{*}{ System } & \multicolumn{4}{|c|}{ Lattice parameters, $\AA$} \\
\cline { 3 - 6 } & & $a$ & $b$ & $c$ & $c / a$ \\
\hline$\alpha-\mathrm{Ta}_{2} \mathrm{O}_{5}$ & Tetragonal & 3.81 & - & 3.609 & 0.947 \\
\hline $\begin{array}{c}\beta-\mathrm{Ta}_{2} \mathrm{O}_{5} \\
\text { (allomeric to } \gamma-\mathrm{Nb}_{2} \mathrm{O}_{5} \text { ) }\end{array}$ & Rhombic & 6.20 & 4.029 & 3.9 & 0.63 \\
\hline
\end{tabular}

The structures of different $\mathrm{Nb}_{2} \mathrm{O}_{5}$ modifications are comprised of two types of $\mathrm{ReO}_{6}$ octahedral blocks, where Re represents a cation. The cross section of one type contains 15 (i.e., $5 \times 3$ ) $\mathrm{NbO}_{6}$ octahedrons connected to each other at the edges to form two-dimensional layers. The other type contains 12 (i.e., $4 \times 3$ ) octahedrons connected in the same manner to form a layer containing tetrahedral gaps, a part of which is occupied by niobium cations [9]. The structures described above enable formation of phases of slightly different compositions $[6,9]$ that contain octahedral and tetrahedral blocks connected at the edges or at the tops.

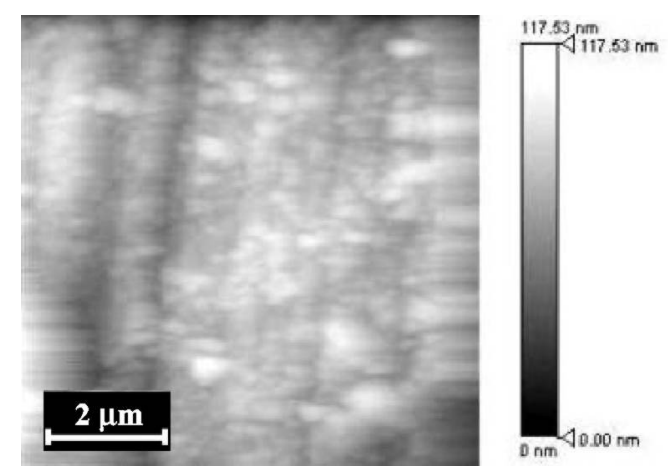

Fig. 4. Nano- $R^{2}$ image of nanosize structures of the $\mathrm{Nb}_{2} \mathrm{O}_{5}$ ceramics processed by the CLF.

The tantalum oxide is also polymorphous. The $\beta$-modification of $\mathrm{Ta}_{2} \mathrm{O}_{5}$ is stable up to $1360^{\circ} \mathrm{C}$. This phase looks like colourless rhombic crystals $(z=11)$ of the space group $P 2 \mathrm{~mm}$, with the melting point $1787^{\circ} \mathrm{C}$ and the density $8.18 \mathrm{~g} / \mathrm{cm}^{3}[5,6,12]$. The $\alpha$-modification of $\mathrm{Ta}_{2} \mathrm{O}_{5}$ is stable above $1560^{\circ} \mathrm{C}$ and looks like grey tetragonal crystals $(z=6)$ of the space group $I 4_{1} /$ amd (the melting point being $1887^{\circ} \mathrm{C}$ and the density $8.37 \mathrm{~g} / \mathrm{cm}^{3}$ ). The lattice parameters of the both crystallographic modifications are presented in Table 2. In particular, the both modifications have the same structural units. They contain $\mathrm{TaO}_{6}$ octahedrons and distorted pentagonal $\mathrm{TaO}_{7}$ bi-pyramids, forming a three-dimensional framework of bonds of a different type [12-15]. 


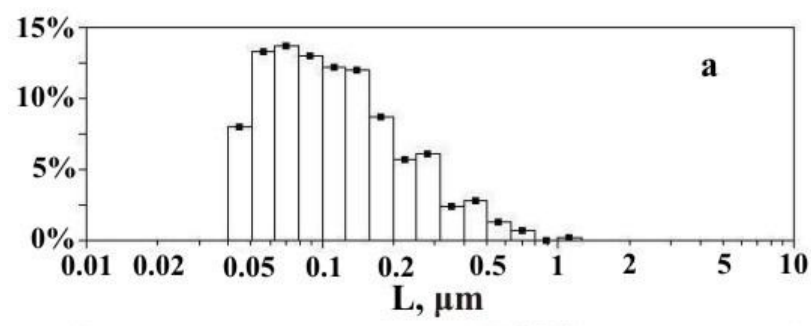

Fig. 5. Differential (a) and integral (b)

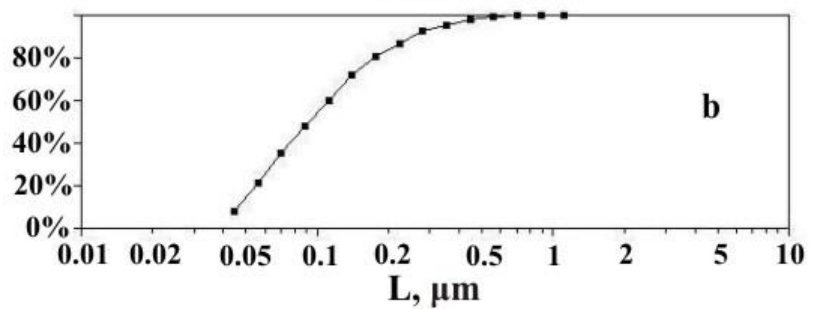
size distributions for the $\mathrm{Nb}_{2} \mathrm{O}_{5}$ ceramic structures shown in Fig. 4.

Obviously, the ceramic samples contain different modifications of $\mathrm{Nb}_{2} \mathrm{O}_{5}$ and $\mathrm{Ta}_{2} \mathrm{O}_{5}$ that belong to different crystalline systems. The X-ray diffraction analysis cannot identify the atomic coordinates of the structure of real samples. Since the calculations of lattice dynamics are also impossible, the Raman spectra remain the only way to identify the real structures of $\mathrm{Nb}_{2} \mathrm{O}_{5}$ and $\mathrm{Ta}_{2} \mathrm{O}_{5}$ $[7,8,9]$. Due to complexity of our structures and some amount of endless chains, blocks, chain parts, and octahedral and tetrahedral blocks of different crystallographic systems [6, 9-13], the Raman bands of the niobium and tantalum oxides can be correctly assigned only in the case of single-crystalline samples and a certain scattering geometry. Nevertheless, some effects of the CLF treatment of the niobium and tantalum oxides can be revealed by the analysis of the Raman spectra. As an example, Fig. 6 shows the Raman spectra obtained for the CLF-processed niobium oxide ceramics.

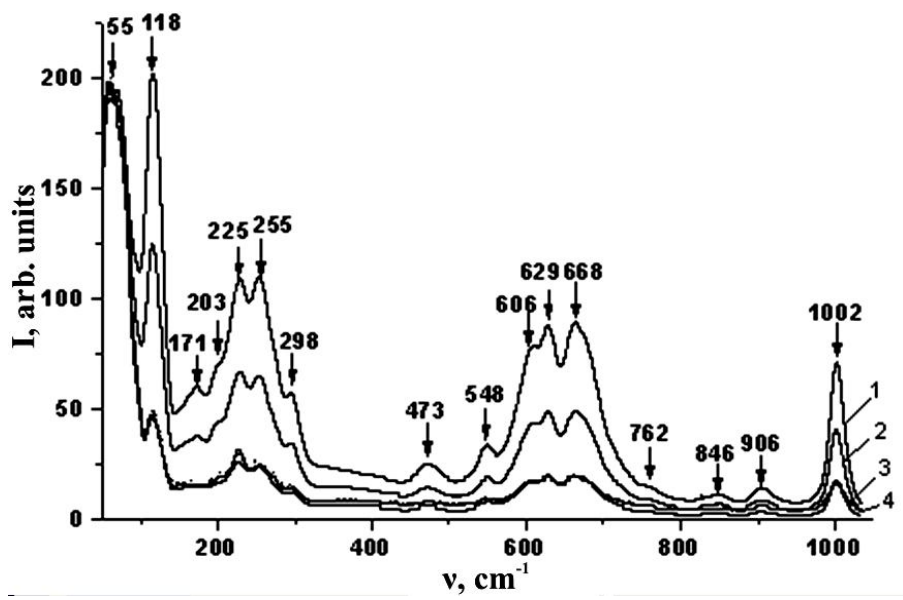

Fig. 6. Raman spectra of ceramic niobium oxide samples processed by the CLF with different intensities: curves 1 to 4 correspond to the relative CLF intensities $I_{r}=1.0,0.5$, 0.25 and 0 , respectively.

The strongest Raman bands are well known to correspond to symmetric vibrations causing the biggest changes in the polarisability of unit cell [2,9]. So, the most intense Raman bands for the case of niobium oxide ceramics should be assigned to the symmetric vibrations. The Raman spectra of the $\mathrm{Nb}_{2} \mathrm{O}_{5}$ samples contain four groups of intense lines separated by wide energy gaps, thus implying that the corresponding vibrations either do not interact or their interaction is negligible.

The bands around $30-120 \mathrm{~cm}^{-1}$ correspond to the vibrations of octahedrons as a whole [14]. The bands in the region of $150-400 \mathrm{~cm}^{-1}$ can be referred to the vibrations of cations located inside 
the octahedrons and tetrahedrons. The bands near $500-1100 \mathrm{~cm}^{-1}$ specify the vibrations of oxygen framework. Notice that the bands located in the region of $500-800 \mathrm{~cm}^{-1}$ should refer to stretching oxygen framework [14-17]. The bands at $850-910 \mathrm{~cm}^{-1}$ are associated with stretches of the oxygen bridges of octahedrons and tetrahedrons. The spectral band located at $548 \mathrm{~cm}^{-1}$ could be attributed to bending of $\mathrm{Nb}-\mathrm{O}-\mathrm{Nb}$ bonds. Finally, the bands around $500-1000 \mathrm{~cm}^{-1}$ may be ascribed to stretching $\mathrm{Nb}-\mathrm{O}$ bonds.

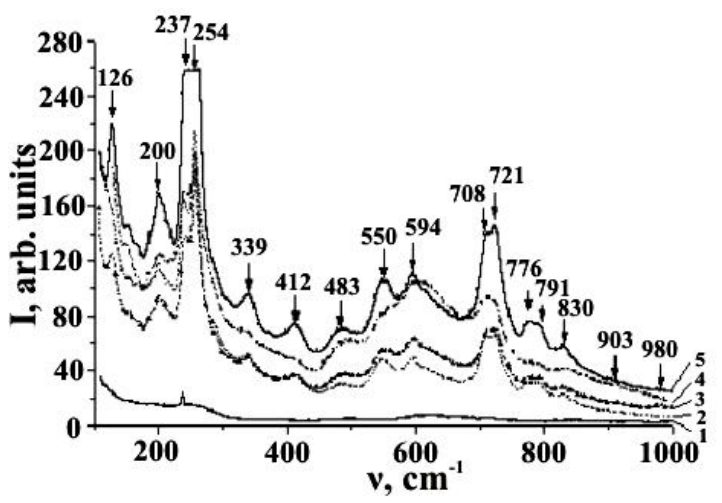

Fig. 7. Raman spectra of tantalum oxide ceramics measured before (curve 1) and after (curves 2 to $5)$ the CLF processing with different relative intensities: $I_{r}=0$ (2), $0.26(3), 0.5(4)$, and $1.0(5)$.

Fig. 6 reveals that the parameters of different Raman bands respond differently to the CLF treatment of the sample. We assume that the intense bands at 55 and $118 \mathrm{~cm}^{-1}$ correspond to symmetric vibrations of the octahedrons and tetrahedrons. At the same time, the bands located in the region of $150-400 \mathrm{~cm}^{-1}$ should be referred to symmetric translational vibrations of niobium ions located in the octahedral and tetrahedral gaps of the structure.

The relative intensities of most of the Raman bands for the CLF-processed $\mathrm{Nb}_{2} \mathrm{O}_{5}$ ceramics increase with increasing CLF intensity. For example, one can observe increasing intensities of the bands located at $118 \mathrm{~cm}^{-1}$ (symmetric librations of tetrahedrons) and $1002 \mathrm{~cm}^{-1}$ (Nb-O stretching) under such conditions. Only the intensity of the band located at $55 \mathrm{~cm}^{-1}$ (symmetric librations of octahedrons) remains unchanged. Therefore breaking of $\mathrm{Nb}-\mathrm{O}-\mathrm{Nb}$ bonds inside the octahedrons and tetrahedrons induced by the CLF manifests itself as a growing intensity of the band referred to stretching $\mathrm{Nb}-\mathrm{O}$ bonds at the free tops. As a result, the structure of the niobium oxide ceramics is broken up into islands of bonded octahedrons and tetrahedrons.

An increase in the number of isolated octahedrons and tetrahedrons occurring with increasing CLF intensity is caused by several processes that accompany each other. First, we have fast (around $10 \mathrm{~s}$ ) melting of the ceramic niobium oxide under the CLF treatment. Second, a partial dissociation in the liquid phase takes place. And third, fast crystallisation under the conditions far from thermodynamic equilibrium should happen after leaving the CLF zone, the latter apparently leading to formation of an island structure. Together with the appearance of micro- and nanostructures under the above treatment, this type of structure contributes to the changes seen in the mechanical characteristics and it should suppress thermal expansion of the samples [4].

As an example, Fig. 7 demonstrates that the biggest changes are detected for the line vibrations [18]. It is also seen from Fig. 7 that the most substantial changes in the Raman spectra for the ceramic tantalum oxide are observed in the region of $450-1000 \mathrm{~cm}^{-1}$, which corresponds to stretching oxygen framework [18]. A weak band at $903 \mathrm{~cm}^{-1}$ is observed in the Raman scattering originated from that part of the sample surface which has been directly irradiated. It should correspond to stretching Ta-O bonds at the free tops of tetrahedrons. On the one hand, the band located at $980 \mathrm{~cm}^{-1}$ and assumed to refer to Ta-O stretching at the free tops of octahedrons is absent (see 
curve 5 in Fig. 7). This suggests a structure of long octahedron chains and fragmented tetrahedron chains. On the other hand, the Raman scattering from the sample surface irradiated with a lower relative intensity $\left(\sim 0.5\right.$ - see curve 4 in Fig. 7) reveals a weak band at $981 \mathrm{~cm}^{-1}$ that corresponds to stretching Ta-O bonds in the isolated $\mathrm{TaO}_{6}$ octahedrons $[13,18]$. The band at $981 \mathrm{~cm}^{-1}$ indicates to a presence of shorter isolated fragments of $\mathrm{TaO}_{6}$ octahedron chains. Moreover, Ta-O-Ta bridges at the ends of these chains are destroyed in those places of the surface where the CLF intensity is substantially lower [18-20].

It is also interesting that the band ascribed to stretching $\mathrm{Ta}-\mathrm{O}$ bonds at the free tops of octahedrons is absent in the Raman scattering from the sample surface directly irradiated by the CLF $\left(I_{r}=1\right)$, whereas practically all the rest of the Raman bands present are the narrowest (Fig. 7). The facts observed by us suggest that the direct CLF irradiation imposes polymerisation of pieces of the octahedron chains, which are linked into extended structures of oxygen polyhedrons [13, 1820]. Of the reasons for the Raman spectra of the CLF-processed ceramic niobium and tantalum oxides to be different, one can remind a higher melting temperature for $\mathrm{Ta}_{2} \mathrm{O}_{5}$ and a higher degree of covalence of $\mathrm{Ta}-\mathrm{O}$ bonds, when compared with that characteristic of $\mathrm{Nb}-\mathrm{O}$ ones.

\section{Conclusions}

The most important and general conclusion drawn on the basis of our results can be summarised as significant changes occurring in the structure of ceramic $\mathrm{Nb}_{2} \mathrm{O}_{5}$ and $\mathrm{Ta}_{2} \mathrm{O}_{5}$ owing to the CLF. This concerns different ordering levels, including the appearance of micro- and nanostructures, the type of chemical bonding, and the polyhedral coordination. The structural changes in the niobium and tantalum oxides manifest themselves in the physical properties, e.g. mechanical characteristics and thermal expansion [4]. The effects of the CLF treatment on the ceramic $\mathrm{Nb}_{2} \mathrm{O}_{5}$ and $\mathrm{Ta}_{2} \mathrm{O}_{5}$ are rather different: the number of the nanosize structures in $\mathrm{Ta}_{2} \mathrm{O}_{5}$ exceeds that of the $\mathrm{Nb}_{2} \mathrm{O}_{5}$ ceramics and the changes in chemical bonding and polyhedral coordination are distinct. The differences observed by us can be explained by differing melting temperatures and degrees of covalence of the chemical bonds $\mathrm{Ta}-\mathrm{O}$ and $\mathrm{Nb}-\mathrm{O}$. A higher melting point for $\mathrm{Ta}_{2} \mathrm{O}_{5}$ decreases the time needed for mutual transformations of the liquid and solid phases after the sample is removed from the zone of irradiation. Quite likely, this should favour formation of the nanosize structures.

\section{References}

1. Andrievsky R A, 1994. The obtaining and properties of nanocrystal refractory compounds. Russ. Chem. Rev. 5: 431-448.

2. Gigin G N, Mavrin B N and Shabanov V F, Optical Raman-spectra of the crystals, Moscow: Science (1984).

3. Palatnikov M, Shcherbina O, Frolov A, Pavlikov V, Chufyrev P, Makarova O and Bormanis $\mathrm{K}, 2009$. Formation of fractal micro- and nano-structures in ceramic tantalum pentoxide under concentrated flux of light and their effect on thermal expansion, Integr. Ferroelectrics. 108: 89-97.

4. Palatnikov M N, Sherbina O B, Frolov A A and Voinich E V, 2011. Micro- and nanostructures, elastic properties and temperature resistance of the ceramics having protective coating of concentric light flux treated niobium oxide, Glass Phys. Chem. 37: 79-83.

5. Goroschenko Ya G, The chemistry of niobium and tantalum, Kyiv: Naukova dumka (1965).

6. Feirbroter F, The chemistry of niobium and tantalum, Moscow: Khimiya (1972).

7. McConnell A A, Anderson J S and Rao N R, 1976. Raman spectra of niobium oxides. Spectrochim. Acta A. 32: 1067-1076. 
8. Balachandran U and Eror N G, 1982. Raman spectrum of the high temperature form of $\mathrm{Nb}_{2} \mathrm{O}_{5}$, J. Mater. Sci. Lett. 1: 374-376.

9. Dobal P S, Dixit A, Katiyar R S, Choosuwan H, Guo R and Bhalla A S, 2002. Micro-Raman scattering in $\mathrm{Nb}_{2} \mathrm{O}_{5}-\mathrm{TiO}_{2}$ ceramics. J. Raman Spectr. 33: 121-124.

10. Miroshnikova L D, 1989. Tantalum oxides, Russ. J. Inorg. Chem. 34: 184-187.

11. Hummel H-U, Fackler R and Remmert P, 1992. Tantaloxide durch Gasphasenhydrolyse, Druckhydrolyse und Transportreaktion aus $2 \mathrm{H}-\mathrm{TaS}_{2}$ : Synthesen von TT- $\mathrm{Ta}_{2} \mathrm{O}_{5}$ und $\mathrm{T}-\mathrm{Ta}_{2} \mathrm{O}_{5}$ und Kristallstruktur von $\mathrm{T}_{-} \mathrm{Ta}_{2} \mathrm{O}_{5}$. Chemische Berichte. 125: 551-556.

12. Stephenson N C and Roth R S, 1971. The crystal structure of the high temperature form of $\mathrm{Ta}_{2} \mathrm{O}_{5}$. J. Sol. State Chem. 3: 145-153.

13. Liu X Q, Han X D, Zhang Z, Ji L F and Jiang Y J, 2007. The crystal structure of high temperature phase $\mathrm{Ta}_{2} \mathrm{O}_{5}$. Acta Materialia. 55: 2385-2396.

14. Sidorov N V, Palatnikov M N, Golubjatnik N A, Kalinnikov V T, Mavrin B N, Asonov V A, Olechnovitch N M, Radyush Yu V and Pushkarev A V, 2004. The display of phase transition ferroelectric-antiferroelectric in $\mathrm{Li}_{0.12} \mathrm{Na}_{0.88} \mathrm{Ta}_{0.4} \mathrm{Nb}_{0.6} \mathrm{O}_{3}$ in Raman-spectra. Opt. Spectrosc. 97: 412-418.

15. Sidorov N V, Volk T R, Mavrin B N and Kalinnikov V T, Lithium niobate: defects, photorefraction, Raman spectra, polaritons. Moscow: Science (2003).

16. Nakamoto K, Infrared spectra of inorganic and coordination compositions, Moscow: Mir (1966).

17. Sidorov N V and Kalinnikov V T, 1999. Structure ordering and Raman spectra in ferroelectric crystals of oxoftor niobates of ammonium, potassium and rubidium $\mathrm{M}_{5} \mathrm{Nb}_{3} \mathrm{OF}_{18}\left(\mathrm{M}=\mathrm{NH}_{4}, \mathrm{~K}\right.$, $\mathrm{Rb})$. Inorg. Mater. 35: 135-151.

18. Brennecka Geoff L, Payne David A, Sarin Pankaj, Zuo J-M, Kriven Waltraud M and Hellwig Holger, 2007. Phase transformations in the high-temperature form of pure and $\mathrm{TiO}_{2}$-stabilized $\mathrm{Ta}_{2} \mathrm{O}_{5}$. J. Amer. Ceram. Soc. 90: 2947-2953.

19. Ikeya $\mathrm{T}$ and Senna $\mathrm{M}, 1989$. Change in the structure during amorphization and crystallization of $\mathrm{Ta}_{2} \mathrm{O}_{5}$ under mechanical stressing: A comparative study with $\mathrm{Nb}_{2} \mathrm{O}_{5}$. J. Non-Crystal Sol. 113: $51-57$.

20. Dobal P S, Katiyar R S, Jiang Y, Guo R, and Bhalla A S, 2000. Micro-Raman scattering and x-ray diffraction studies of $\left(\mathrm{Ta}_{2} \mathrm{O}_{5}\right)_{1-\mathrm{x}}\left(\mathrm{TiO}_{2}\right)_{\mathrm{x}}$ ceramics, J. Appl. Phys. 87: 8688-8694.

Palatnikov M., Shcherbina O., Sidorov N. and Bormanis K., 2012. The structure of niobium and tantalum oxides processed by concentrated light flux. Ukr.J.Phys.Opt. 13: a $-\mathrm{h}$.

Анотація. У роботі виявлено суттєві зміни структури внаслідок обробки керамік $\mathrm{Nb}_{2} \mathrm{O}_{5} i$ $\mathrm{Ta}_{2} \mathrm{O}_{5}$ концентрованим потоком світла. Ці зміни полягають у появі мікро- $i$ наноструктур, зміні типу хімічного зв'язку, координаційного числа та ін. Зміни структури виявляються у змінах фізичних властивостей. Впливи концентрованого потоку світла на кераміки $\mathrm{Nb}_{2} \mathrm{O}_{5} i$ $\mathrm{Ta}_{2} \mathrm{O}_{5}$ різні. Зокрема, кількість нанорозмірних структур, що з'являються в кераміці $\mathrm{Ta}_{2} \mathrm{O}_{5}$, вища, а зміни хімічного зв'язку і координаційних чисел - різні. Ці відмінності пояснюються відмінностями температур плавлення керамік $\mathrm{Nb}_{2} \mathrm{O}_{5}$ та $\mathrm{Ta}_{2} \mathrm{O}_{5}$ i ступеня ковалентності хімічних зв'язків $\mathrm{Nb}-\mathrm{O}$ і $\mathrm{Ta}-\mathrm{O}$. 